\title{
Digital games in medical education: Key terms, concepts, and definitions
}

\author{
Shoaleh Bigdeli ${ }^{1 *}$, David Kaufman ${ }^{2}$ \\ Received: 04 Mar $2017 \quad$ Published: 2 Sep 2017
}

\begin{abstract}
Background: Game-based education is fast becoming a key instrument in medical education.

Method: In this study, papers related to games were filtered and limited to full-text peer-reviewed published in English.

Results: To the best of researchers' knowledge, the concepts used in the literature are varied and distinct, and the literature is not conclusive on the definition of educational games for medical education.

Conclusion: This paper attempts to classify terms, concepts and definitions common to gamification in medical education.
\end{abstract}

Keywords: Game, Simulation Game, Medical Education

Copyright $\odot$ Iran University of Medical Sciences

Cite this article as: Bigdeli S, Kaufman D. Digital games in medical education: Key terms, concepts, and definitions. Med J Islam Repub Iran. 2017(2 Sep);31:52.https://doi.org/10.14196/mjiri.31.52

\section{Introduction}

Games are as old as human beings; however, the history of educational games was first detected at the time when Socrates and Plato used a kind of verbal play in their "dialogues". In the $19^{\text {th }}$ century, Froebel integrated "learning," "game" and "play"; and, in the 1990s, digital games were developed further and became dramatically widespread among the youth, resulting in a cohort of incoming students accustomed to digital game plays (1).

A considerable amount of literature has been published on digital games, and a number of researchers have sought to define the key concepts and essential elements $(2,3)$. There are five attributes encapsulating the concept of educational games: player or players, conflicts, rules, predetermined goal of the game, artificial nature of games (4), and since the focus of this review study is on educational games, the pedagogical nature of the game provides a sixth attribute.

Integration of digital educational games into existing medical education context is a challenge and a current focus of attention in studies for teachers, learners and cli-

\footnotetext{
Corresponding author: Dr Shoaleh Bigdeli,sbigdeli@alumni.sfu.ca
}

1. Center for Educational Research in Medical Sciences (CERMS), Department of Medical Education, Faculty of Medicine, Iran University of Medical Sciences, Tehran, Iran.

2. Faculty of Education, Simon Fraser University (SFU), Vancouver, BC, Canada. nicians in settings of medical education. Some studies have emphasized the positive influence of games over traditional teaching methods for educational purposes $(5$, $6)$. On the other hand, several authors have claimed that students with diverse learning styles (e.g. visual and aural, $\mathrm{read} / \mathrm{write}$, and kinesthetic) can benefit from educational games (7) provided that individual personal characteristics be considered in the instructional design of the games.

In medical education, digital games have been presented in different digital formats such as simulations, virtual environments, social and cooperative plays and alternative reality games (5-10); however, simulations are different from games in nature, as are virtual environments. Therefore, in this study, we included simulation games and the virtual environments containing a digital game. As medical professions are practice-based, a majority of gamebased programs focus on procedural skills (e.g. surgery, laparoscopy) that can improve patient safety, help limit burnout and fulfill the promise of competency-based education (11). The current technology of digital games has

$\uparrow$ What is "already known" in this topic:

- Educational games in medical education are growing fast,

- The literature is not conclusive on the definition of educational games in medical education.

$\rightarrow$ What this article adds:

- The pedagogical nature of the game is a sixth attribute encapsulating the concept of educational games

- Characteristics of the learners must be considered in medical education game design

- Educational games in medical education can be classified according to cognitive, psychomotor, and affective learning domains. 
the potential to provide virtual experiences in a more costeffective manner, and learners can be exposed to diverse case scenarios enabling them to create and evaluate both positive and negative outcomes of clinical procedures (12). In addition, this technology provides a safe environment $(13,14)$ for learners to gain skills and selfconfidence without being stressed about making the realworld judgments, as well as ensuring patients' safety. Unlike real-world practice which might endanger patients' safety, the educational game technology provides a safe environment in which learners can practice and gain skills and experiences self-confidently without threats of the real-world.

Although extensive research has been carried out on the application of digital games in medical education, to the best of researchers' knowledge, there are few studies which adequately cover the terms, and concepts, and to the best of researchers' knowledge none of them provides a sound classification which is based on cognitive, psychomotor and attitude domains of learning.

This review study provides an overview of terms, concepts, and definitions used as efficient educational elements of digital games in medical education. Elaborating these concepts in all disciplines of medical education is beyond the scope of this paper, and we will only focus on terms and concepts used in medicine, nursing, pharmacy, and dentistry.

\section{Methods}

This review study was conducted from September to December 2015 via SFU library, CINAHL Complete, Cochrane Library (Cochrane CENTRAL and Cochrane Reviews), EBSCOhost, Elsevier Science Direct, ERIC, PsycINFO, PsycARTICLES, PubMed, PubMed Central (PMC), PubMed/MEDLINE, with Search terms (AND, OR, NOT) and keywords: game, gamified, gamification, computer game, digital game, electronic game, video game, systematic review, meta-analysis, meta-analysis, health professions, medical, nursing, pharmacy, dentistry, education in peer-reviewed journal articles to find all digital games related to medical education disciplines of medicine, nursing, pharmacy and dentistry.

\section{Inclusion and exclusion criteria}

Papers related to games were filtered and limited to fulltext peer-reviewed papers published in English in 20102015. The papers were included if addressing digital games in medical education (disciplines of medicine, nursing, pharmacy and dentistry), and if students were participants of the study. The aforementioned disciplines were selected to narrow the scope of the paper and to explore the topic in these fields more precisely.

The articles were excluded if the topics were not related to medical education, were not available in full text, the participants were patients, teachers and/or staff only, the participants composed of residency students and/or medical professionals (e.g., surgeons, specialists) only.

Moreover, studies addressing blogs, discussion boards, podcasts, videos and video-conferencing, and non-digital games were excluded. Finally, studies on apps for smartphones, tablets, portable music players, and topics of patient management, patient education, teacher, and staff education were excluded too.

Titles and abstracts, resulting from the initial online search with selected MeSH and free text terms related to digital educational games, were screened for relevance and eligibility for full-text retrieval. Additional articles were searched through citation by manual checking of the reference sections of the sourced articles. The full texts recognized eligible were also screened, and the researchers resolved their disagreements by discussion if they were any. Finally, the selected relevant articles retrieved were those that focused on the use of specific educational games for learning in four disciplines of medicine, nursing, pharmacy, and dentistry.

\section{Results}

\section{Postmodern generation of game players}

According to the findings of the present study, diverse terminology is used to define current generation of medical education students as native speakers of digital educational games. They are mainly divided into seven categories defining highly active participants who spend countless hours on playing digital games individually or in groups. They seek enjoyment and power to use technology limitlessly (15) and in a timelessly manner. This multitask generation demands something more than "textbooks" and non-interactive "lectures" for learning (16) (Table1).

\section{Digital games and medical education}

A digital educational game for specific purposes of medical education is an electronic game involving interaction of medical practitioners and students with a user interface in an offline and/or online mode reference. Popular electronic devices used by medical professionals include but not limited to desktop computers, laptops, tablets, ipads, ipods, and smartphones. The findings of the present study showed that there is no clear distinction between "game", "simulation", and "simulated game", they are used interchangeably in the literature, and there is a relative overlap in definitions. Games and simulations bear common elements of rules and regulations, mechanics, engagement, collaboration and interactivity with highthinking and mental engagement. However, in practice, games enjoy elements of competition, fun, and entertainment while simulations are more serious and similar to real life situations and usually lack these features. Current terms and concepts used are presented in (Table2). 
Table 1.Terminology to define current generation of health professions students

\begin{tabular}{|c|c|c|}
\hline Term & Citation & Definition \\
\hline "Homozappien" & {$[15]$} & Postmodern generation of learners \\
\hline \multirow[t]{3}{*}{ Millennials } & {$[7,17]$} & $\begin{array}{l}\text { Current aspiring medical students who read less and are more comfortable } \\
\text { with electronic interactivity } \\
\text { Students born in or after } 1982 \text { who expect instantaneous responses and are } \\
\text { multitask prefer active, engaging activities rather than traditional teacher- } \\
\text { centered activities, prefer teamwork and social networking, excitement, enter- } \\
\text { tainment and technology }\end{array}$ \\
\hline & {$[18]$} & $\begin{array}{l}\text { Generation of learners with ubiquitous access to information technology } \\
\text { throughout their education }\end{array}$ \\
\hline & [19] & Net Generation \\
\hline $\mathrm{N}$-[for Net]-gen & & "New" students of today \\
\hline \multicolumn{3}{|l|}{ D-[for Digital]-gen } \\
\hline Net generation & {$[7,17,18,19,22]$} & $\begin{array}{l}\text { Born between } 1982-1991 \text {, more comfortable with information and commu- } \\
\text { nications technology environments rich in audio-visual multimedia, prefer } \\
\text { first person, active, engaging self-directed activities rather than traditional } \\
\text { teacher-centered activities, interested in excitement, fun and entertainment, } \\
\text { expect immediate responses and are achievement orientated, prefer a clear } \\
\text { learning outcome rather than ambiguity, spend many hours playing computer } \\
\text { games, prefer collaborative teamwork and social networking, like to talk } \\
\text { about what they are doing, especially to other members of their peer group }\end{array}$ \\
\hline
\end{tabular}

Moreover, in dentistry, simulations, robotics and haptic technology focusing on psychomotor skills (8) are of major concern, and it appears that simulation is more seriousand similar to real life experiences, and elements of fun and entertainment are of less importance.

There are at least 16 categories of digital games, availa- ble for educational and commercial purposes, some of which can be used for medical professions education (Table3). Minesweeper as a puzzle game, Grey's anatomy as a TV show format and scratch offs are some of the examples.

Digital games of medical professions improving cog-

Table 2.The terminology of games for educational purposes

\begin{tabular}{|c|c|c|}
\hline Terms & Definition & Citation \\
\hline Game & $\begin{array}{l}\text { An outcome-oriented activity that proceeds according to a set of } \\
\text { rules and often involves focused decision-making } \\
\text { An activity with a competitive element, the aim of which was } \\
\text { to promote learning and the retention of educational material }\end{array}$ & {$[23]$} \\
\hline Gaming & The use of game design elements to increase user engagement & {$[24]$} \\
\hline Gamification & $\begin{array}{l}\text { The process of applying gaming mechanics, frameworks and principles (competition, rewards, enjoyment) to a } \\
\text { nongame-related endeavor (situations, contexts, and scenarios, e.g. workplace collaboration, marketing, educa- } \\
\text { tion, military, and medical services) to increase user engagement. }\end{array}$ & $\begin{array}{c}{[5,11,18,25,} \\
26,27]\end{array}$ \\
\hline Game resources & Workplace pictures, animations or other visual assets, sounds, videos, etc. & [27] \\
\hline $\begin{array}{l}\text { Educational } \\
\text { game }\end{array}$ & $\begin{array}{l}\text { A competitive experiential learning activity with precise rules and various degrees of chance, in which players } \\
\text { compete through knowledge and skill in an attempt to reach a specified goal } \\
\text { A competitive activity with a prescribed setting constrained by rules and procedures, stimulate higher thinking } \\
\text { such as analysis, synthesis, and evaluation, make the learning process fun and exciting and reduces stress and } \\
\text { anxiety, which in turn may increase retention }\end{array}$ & $\begin{array}{c}{[7,9,10,13} \\
28,29]\end{array}$ \\
\hline $\begin{array}{l}\text { Game-based } \\
\text { learning }\end{array}$ & Attempts to situate learners as players and provide learning activities within a recognizable game delivery model & \\
\hline $\begin{array}{l}\text { Game-informed } \\
\text { learning }\end{array}$ & $\begin{array}{l}\text { Suggests that it is possible to make teaching practices more game-like by applying the principals of gameplay } \\
\text { without necessarily having to be committed to developing a game to produce the same compelling, immersive } \\
\text { learning experiences }\end{array}$ & {$[30]$} \\
\hline
\end{tabular}




\begin{tabular}{|c|c|c|}
\hline \multicolumn{3}{|l|}{ Cntd Table 2} \\
\hline Free to play games & $\begin{array}{l}\text { F2P software space are ubiquitous and free for users access. Meanwhile developers use data } \\
\text { for insights on how to increase player acquisition and engagement }\end{array}$ & [18] \\
\hline Video game & $\begin{array}{l}\text { A mental contest with a goal or objective played on a digital device according to rules that } \\
\text { determine what a player can and cannot do inside the game world }\end{array}$ & [31] \\
\hline Serious games & $\begin{array}{l}\text { Interactive digital technologies whose primary purpose is to educate rather than entertain; } \\
\text { include games and simulations that explore interpersonal development, diplomacy, organiza- } \\
\text { tion, health, education, management, and leadership }\end{array}$ & {$[31,32]$} \\
\hline Serious gaming & $\begin{array}{l}\text { Educational or virtual gaming as "any piece of software that merges a non-entertaining pur- } \\
\text { pose (serious) with a video game structure (game)." }\end{array}$ & {$[33,34]$} \\
\hline Serious educational game (SEGs) & Games developed primarily for educational purposes & [31] \\
\hline \multirow[t]{3}{*}{ Simulation } & $\begin{array}{l}\text { A sort of "concentrated reality" that offers opportunities to rehearse life-saving skills and } \\
\text { knowledge as often as necessary }\end{array}$ & [21] \\
\hline & \multirow{2}{*}{$\begin{array}{l}\text { Another category of "serious games", tend to be more realistic, range from simple, case } \\
\text { study video scenarios to complex computer simulations that interface with lifelike manikins } \\
\text { have different forms of role-playing, computer-based, and manikin-based } \\
\text { Practical exercises that lack the competitive elements of games }\end{array}$} & [33] \\
\hline & & [14] \\
\hline Simulation game & $\begin{array}{l}\text { Any computerized game whose chief mission is not entertainment and all entertainment } \\
\text { games which can be reapplied to a different mission other than entertainment }\end{array}$ & [35] \\
\hline Simulation key elements & $\begin{array}{l}\text { Feedback, repetitive practice, curriculum integration, range of difficult, multiple learning } \\
\text { strategies, controlled environment, individualized learning, defined learning objectives }\end{array}$ & {$[24,30]$} \\
\hline $\begin{array}{l}\text { Advanced Navigational Simulation } \\
\text { (Global Positioning-Type Systems) }\end{array}$ & $\begin{array}{l}\text { A surgical computerized modality based on the synchronization of the intraoperative position } \\
\text { of the instruments in which the surgical instruments are accurately tracked and targeted to a } \\
\text { preplanned location within the surgical field with the imaging of the patient's anatomy previ- } \\
\text { ously obtained by computed tomography (CT) or magnetic resonance imaging (MRI) }\end{array}$ & [8] \\
\hline \multirow[t]{2}{*}{ Virtual reality } & \multirow{2}{*}{$\begin{array}{l}\text { The recreation of environments or objects as a complex, computer-generated image capable } \\
\text { of encompassing most medical issues and can be used by all health care disciplines } \\
\text { Creates virtual worlds using mathematical models and computer programs, allowing users to } \\
\text { move in the created virtual world in a way similar to real life }\end{array}$} & [21] \\
\hline & & [8] \\
\hline Second Life & $\begin{array}{l}\text { A three-dimensional technology that provides simulation- based virtual settings that provides } \\
\text { a way to combine new simulation technologies with role-plays to enhance instruction }\end{array}$ & \\
\hline Robotics & \multicolumn{2}{|l|}{$\begin{array}{l}\text { A technology focused on more realistic mannequins able to simulate movements and verbal } \\
\text { expression of emotions like pain that provides an opportunity for instructors to remote control } \\
\text { them to teach the students to anticipate patient's behavior while working }\end{array}$} \\
\hline Haptic technology & \multicolumn{2}{|l|}{$\begin{array}{l}\text { A technology that provides users with the ability to interact with virtual objects within the } \\
\text { virtual environment via feel and touch }\end{array}$} \\
\hline \multicolumn{3}{|c|}{ 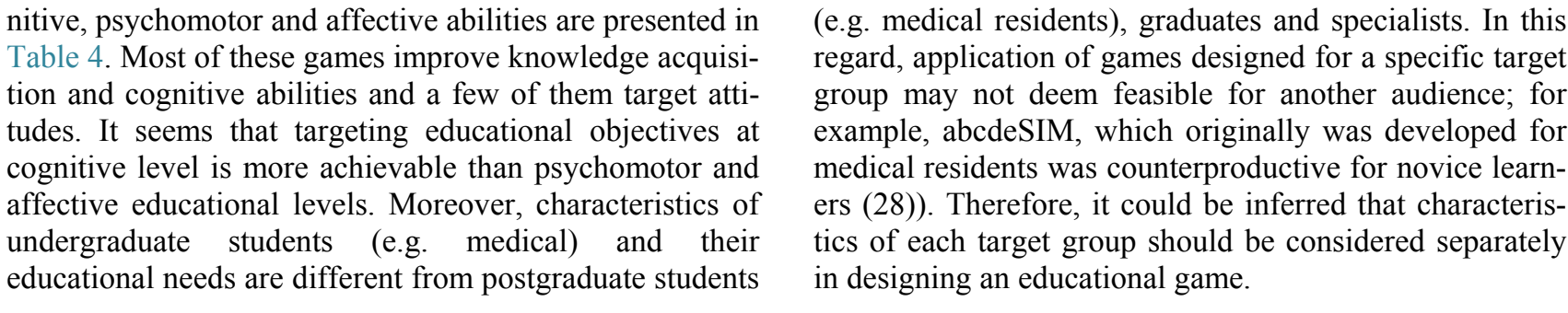 } \\
\hline
\end{tabular}

Table 3.Types of digital educational games for Medical Education

\begin{tabular}{lcl}
\hline Types of Games & Citations & \multicolumn{1}{c}{ Game Name and Designer (Examples retrieved from Wikipedia.org) } \\
\hline Card games & {$[13,34,36]$} & Magic: The Gathering (Richard Garfield) \\
Board games & {$[13,34]$} & Ticket to ride (Alan R. Moon) \\
Simulation & {$[13]$} & The Sims Online (William Ralph Wright) \\
& {$[13,22]$} & Final Fantasy XI (Hiromichi Tanaka) \\
Role-playing & {$[37]$} & Geriatric Medication Game, Saint Louis College of Pharmacy \\
Frame games & {$[36]$} & Portal (Valve Corporation) \\
Puzzles & {$[22,36]$} & Minesweeper (Curt Johnson) \\
\hline
\end{tabular}


Cntd Table 3

\begin{tabular}{lcl}
\hline Cross-words & {$[36]$} & Digital Cross Words (USA today) \\
TV show format & {$[13]$} & Grey's Anatomy (Shonda Rhimes) \\
Virtual learning 3D platform & {$[21]$} & $\begin{array}{l}\text { Second Life (Linden lab) } \\
\text { The Chamber (Rick Schwartz) }\end{array}$ \\
Same show & {$[34]$} & $\begin{array}{l}\text { Concentration 9 (Lora O'Neil) } \\
\text { Multi media }\end{array}$ \\
Strategy game & & Magnet Mania Scratch off (TCD Communications, NY) \\
3D First person shooter game & {$[22]$} & Dungeons and Dragons (Gary Gygax and Dave Arneson) \\
2D non-first-person shooter game & {$[22,38]$} & Half-Life (Valve Corporation) \\
Arcade games & {$[38]$} & Chessmaster (Ubisoft Romania) \\
\hline
\end{tabular}

Table 4. Classification of digital educational games according to cognitive, psychomotor, and affective learning domains: Examples

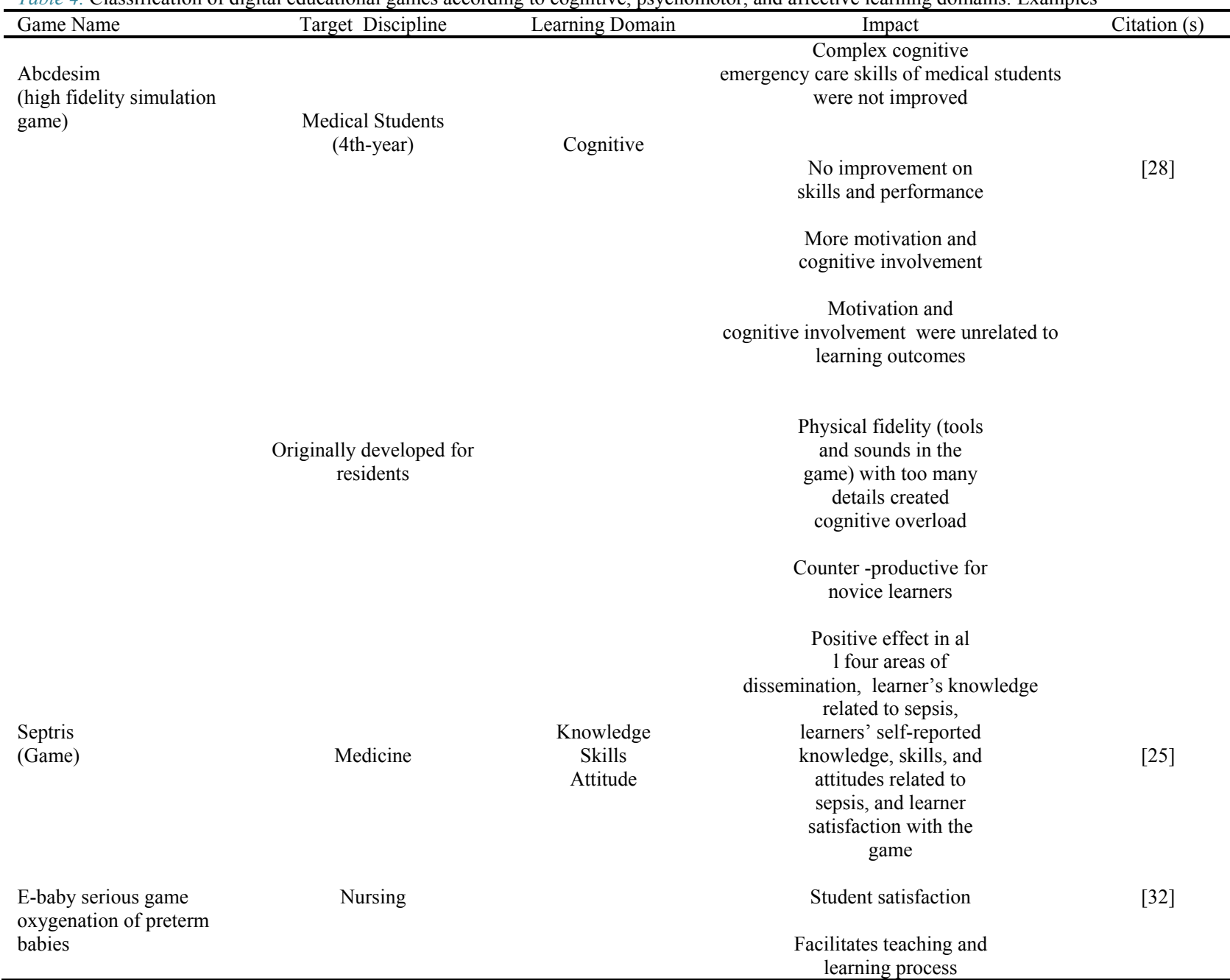

\section{Conclusion}

This paper was an attempt to provide an informative overview of the elements appearing in studies related to educational games. It was a comprehensive review of the existing literature on educational games with a specific focus on medical education, addressing terminology common to digital educational games,defining current millennial learners, different types of games, and classifi- cation of games on the basis of the cognitive, psychomotor and affective learning domains. Also, to the best of our knowledge, it is the first study which summarizes the major terminology of game players and common terms related to digital educational games of medical education in a comprehensive and concise manner.

Although the study used a comprehensive search strategy, it had a limited scope of review. The findings apply to 


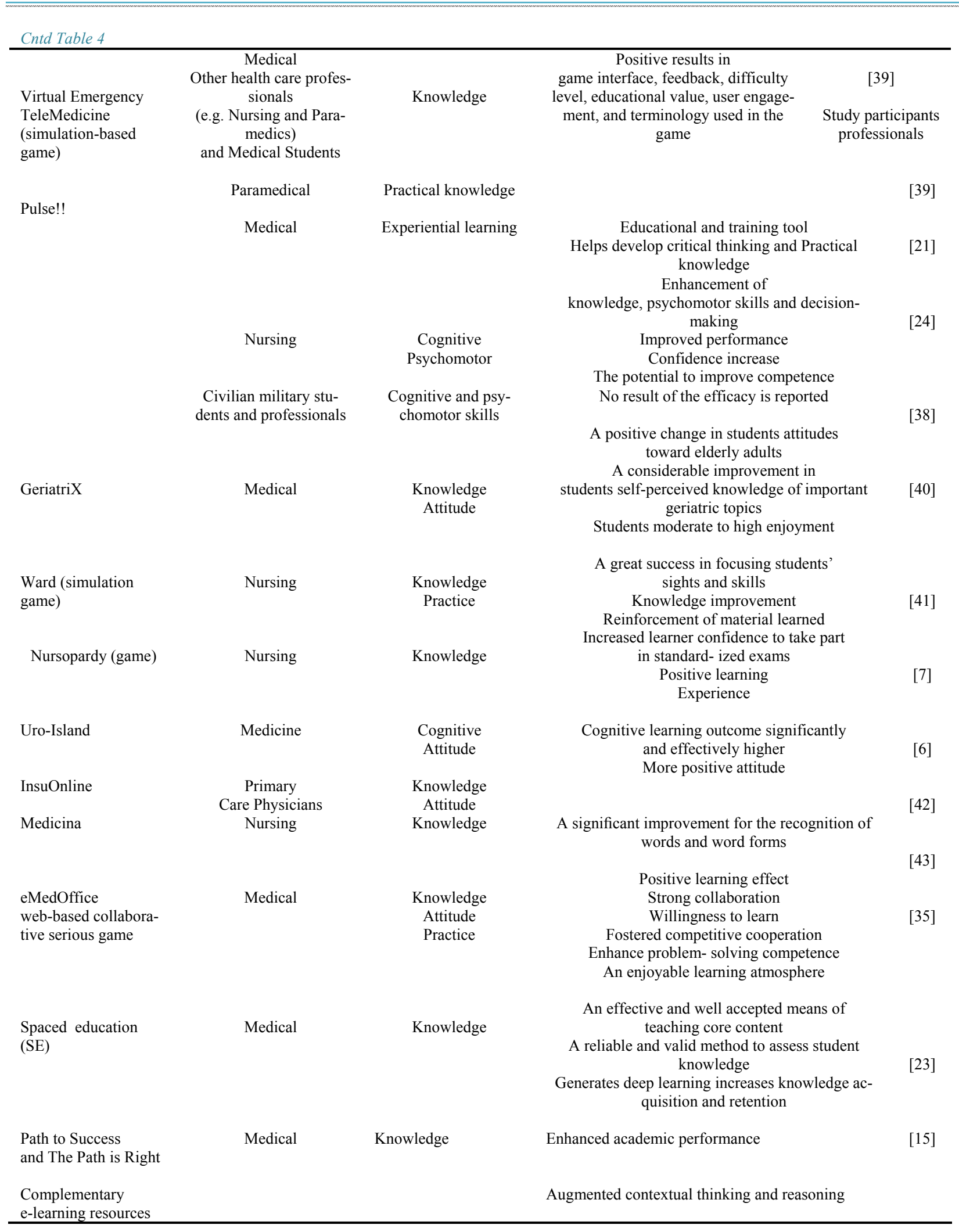

some formats sometimes labeled games, role playing, simulations and serious games due to their blurred margins which make the discrimination unlikely. Even though rigorous attempts were made to ensure that this review covered all articles on educational digital games in the disciplines of medicine, nursing, dentistry, and pharmacy, some papers might not have been identified.
Finally, we would suggest that a collaboration of a team consisting of curriculum designers, educational psychologists, cognitive psychologists, educational philosophers and technical game designers for developing educational games in health professions education is strongly recommended. 


\section{Acknowledgements}

Funding of this paper is provided by AGE-WELL National Centre of Excellence (Project WP4.2)

\section{Conflict of Interests}

The authors declare that they have no competing interests.

\section{References}

1. http://www.instituteofplay.org/about/context/history-of-games-lear ning/

2. Sauvé L, Renaud L, Kaufman D, Marquis JS. Distinguishing between games and simulations: A systematic review. Educat Techno Soc. 2007 Jul 1;10(3):247-56.

3. Rutter J, Bryce J, editors. Understanding digital games. Sage; 2006 Apr 20.

4. Sauvé L, Renaud L, Kaufman D. Games, simulations and simulations games for learning: Definitions and distinctions. D. Kaufman \& L. Sauvé. Educational gameplay and simulation environments: Case studies and lessons learned. 2010 Jan 31:1-26

5. Pettit RK, McCoy L, Kinney M, Schwartz FN. Student perceptions of gamified audience response system interactions in large group lectures and via lecture capture technology. BMC Med educat. 2015 May 22;15(1):1.

6. Boeker M, Andel P, Vach W, Frankenschmidt A. Game-based elearning is more effective than a conventional instructional method: A randomized controlled trial with third-year medical students. PloS one. 2013 Dec 5;8(12): e82328.

7. Boctor L. Active-learning strategies: The use of a game to reinforce learning in nursing education. A case study. Nurse Educat pract. 2013 Mar 31;13(2):96-100.

8. Gottlieb R, Vervoorn JM, Buchanan J. Simulation in dentistry and oral health. In the Comprehensive Textbook of Healthcare Simulation Springer New York. 2013 (pp. 329-340).

9. Akl EA, Pretorius RW, Sackett K, Erdley WS, Bhoopathi PS, Alfarah $Z$, Schünemann HJ. The effect of educational games on medical students' learning outcomes: a systematic review: BEME Guide No 14. Med Teac. 2010 Jan 1;32(1):16-27.

10. Akl EA, Kairouz VF, Sackett KM, Erdley WS, Mustafa RA, Fiander M, Gabriel C, Schünemann H. Educational games for health professionals. Cochrane Database Syst Rev. 2013 Jan 1;3(3).

11. Yunyongying P. Gamification: Implications for curricular design. Journal of graduate medical education. 2014 Sep;6(3):410-2.

12. Hess J, Shrum K. The new media and the acceleration of medical education. On the Horizon. 2011 Sep 27;19(4):331-40.

13. Alfarah Z, Schünemann HJ, Akl EA. Educational games in geriatric medicine education: A systematic review. BMC geriatrics. $2010 \mathrm{Apr}$ $23 ; 10(1): 1$.

14. Blakely G, Skirton H, Cooper S, Allum P, Nelmes P. Use of educational games in the health professions: A mixed-methods study of educators' perspectives in the UK. Nurs Health Sci. 2010 Mar 1;12(1):2732 .

15. Kanthan R, Senger JL. The impact of specially designed digital games-based learning in undergraduate pathology and medical education. Arch Pathol Lab Med. 2011 Jan;135(1):135-42.

16. Colbert JA, Chokshi DA. Technology in medical education-Osler meets Watson. J Gen Intern Med. 2014 Dec;29(12):1584.

17. Oblinger D, Oblinger JL, Lippincott JK. Educating the net generation. Boulder, Colo.: EDUCAUSE, c2005. 1 v.(various pagings): illustrations.; 2005.

18. Nevin CR, Westfall AO, Rodriguez JM, Dempsey DM, Cherrington A, Roy B, Patel M, Willig JH. Gamification as a tool for enhancing graduate medical education. Postgrad Med J. 2014 Dec 1;90(1070):68593.

19. Sandars J, Morrison C. What is the Net Generation? The challenge for future medical education. Med Teach. 2007 Jan 1;29(2-3):85-8.

20. Prensky M. Digital natives, digital immigrants part 1 . On the horizon. 2001 Sep 1;9(5):1-6.

21. Dunne JR, McDonald CL. Pulse!!: a model for research and development of virtual-reality learning in military medical education and training. Military Med. $2010 \mathrm{Jul} ; 175(7 \mathrm{~S}): 025-7$.

22. Kron FW, Gjerde CL, Sen A, Fetters MD. Medical student attitudes toward video games and related new media technologies in medical education. BMC Medl Educat. 2010 Jun 24;10(1):1.

23. Kerfoot BP, Baker H, Pangaro L, Agarwal K, Taffet G, Mechaber AJ, Armstrong EG. An online spaced-education game to teach and assess medical students: a multi-institutional prospective trial. Aca Med. 2012 Oct 1;87(10):1443-9.

24. Cook NF, McAloon T, O'Neill P, Beggs R. Impact of a web based interactive simulation game (PULSE) on nursing students' experience and performance in life support training-A pilot study. Nurse Educ Today. 2012 Aug 31;32(6):714-20.

25. Evans KH, Daines W, Tsui J, Strehlow M, Maggio P, Shieh L. Septris: a novel, mobile, online, simulation game that improves sepsis recognition and management. Acad Med. 2015 Feb;90(2):180.

26. Kim S. Decision Support Model for Introduction of Gamification Solution Using AHP. Sci World J. 2014 Apr 23;2014.

27. Torrente J, Borro-Escribano B, Freire M, del Blanco Á, Marchiori EJ, Martínez-Ortiz I, Moreno-Ger P, Fernández-Manjón B. Development of game-like simulations for procedural knowledge in healthcare education. IEEE Trans LearningTechno. 2014 Jan;7(1):69-82.

28. Dankbaar ME, Alsma J, Jansen EE, Merrienboer JJ, Saase JL, Schuit SC. An experimental study on the effects of a simulation game on students' clinical cognitive skills and motivation. Adv Health Sci Educ. 2015 Oct 3:1-7.

29. Aburahma MH, Mohamed HM. Educational Games as a Teaching Tool in Pharmacy Curriculum. Am JPharma Educ. 2015 May; 79(4):59-

30. Begg M. Leveraging game-informed healthcare education. Medical Teacher. 2008 Jan 1;30(2):155-8.

31. Rodriguez DM, Teesson M, Newton NC. A systematic review of computerised serious educational games about alcohol and other drugs for adolescents. Drug Alcohol Rev. 2014 Mar 1;33(2):129-35.

32.Fonseca LM, Dias Dm, Góes FD, Seixas CA, Scochi CG, Martins JC, Rodrigues MA. Development of the e-Baby serious game with regard to the evaluation of oxygenation in preterm babies: contributions of the emotional design. Comput Inform Nurs. 2014 Sep 1;32(9):428-36.

33. Gleason AW. RELM: Developing a Serious Game to Teach Evidence-Based Medicine in an Academic Health Sciences Setting. Med Ref Serv Q. 2015 Jan 2;34(1):17-28.

34. Carifa L, Goodin HJ. Using games to provide interactive perioperative education. AORN J. 2011 Oct 31;94(4):370-6.

35. Hannig A, Kuth N, Özman M, Jonas S, Spreckelsen C. eMedOffice: A web-based collaborative serious game for teaching optimal design of a medical practice. BMC Med Educ. 2012 Oct 31;12(1):1.

36. Saxena A, Nesbitt R, Pahwa P, Mills S. Crossword puzzles: active learning in undergraduate pathology and medical education. Arch Pathol Lab Med. 2009 Sep;133(9):1457-62.

37. Chen AM, Kiersma ME, Yehle KS, Plake KS. Impact of an Aging Simulation Game on Pharmacy Students' Empathy for Older Adults. Am JPharma Educ. 2015 Jun 25;79(5).

38. Kato PM. Video games in health care: Closing the gap. Rev Gen Psycho. 2010 Jun;14(2):113.

39. Nicolaidou I, Antoniades A, Constantinou R, Marangos C, Kyriacou E, Bamidis P, Dafli E, Pattichis CS. A Virtual Emergency Telemedicine Serious Game in Medical Training: A Quantitative, Professional Feedback-Informed Evaluation Study. JMed Int Res. 2015 Jun;17(6).

40. Pol MH, Lagro J, Fluit LR, Lagro-Janssen TL, Rikkert O, Marcel GM. Teaching Geriatrics Using an Innovative, Individual-Centered Educational Game: Students and Educators Win. A Proof-of-Concept Study. J Am Geriatr Soc. 2014 Oct 1;62(10):1943-9.

41. Stanley D, Latimer K. 'The Ward': A simulation game for nursing students. Nurse Educ Pract. 2011 Jan 31;11(1):20-5.

42. Diehl LA, Souza RM, Alves JB, Gordan PA, Esteves RZ, Jorge ML, Coelho IC. InsuOnline, a serious game to teach insulin therapy to primary care physicians: design of the game and a randomized controlled trial for educational validation. JMIR Res Proto. 2013;2(1):e5.

43. Müller A. Research-based design of a medical vocabulary videogame. Int J Pedago Learn. 2012 Nov 1;7(2):122-34. 